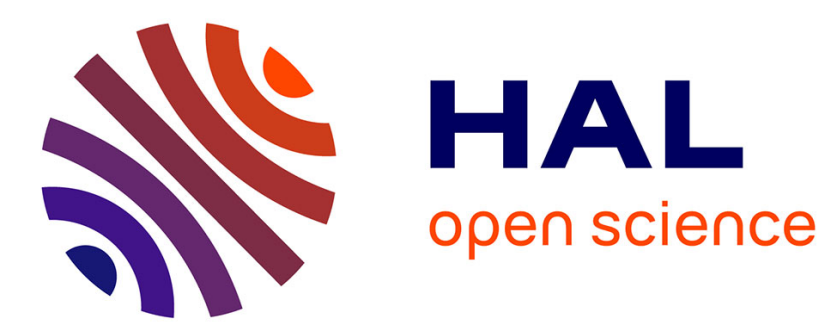

\title{
Carbon in the Moon
}

Bruno Scaillet

\section{To cite this version:}

Bruno Scaillet. Carbon in the Moon. Nature Geoscience, 2015, 8, pp.747-748. 10.1038/ngeo2530 . insu-01192577

\section{HAL Id: insu-01192577 https://hal-insu.archives-ouvertes.fr/insu-01192577}

Submitted on 16 Dec 2015

HAL is a multi-disciplinary open access archive for the deposit and dissemination of scientific research documents, whether they are published or not. The documents may come from teaching and research institutions in France or abroad, or from public or private research centers.
L'archive ouverte pluridisciplinaire HAL, est destinée au dépôt et à la diffusion de documents scientifiques de niveau recherche, publiés ou non, émanant des établissements d'enseignement et de recherche français ou étrangers, des laboratoires publics ou privés.

\section{(1)}

Distributed under a Creative Commons Attribution - NonCommercial - NoDerivatives 44.0 


\title{
Carbon in the Moon
}

\author{
$\underline{\text { Bruno Scaillet }}$
}

The Moon was once thought to be depleted in volatile elements. Analyses of the carbon contents of lunar volcanic glasses reveal that carbon monoxide degassing could have produced the fire-fountain eruptions from which these glasses were formed.

\section{Subject terms: Geochemistry, Inner planets, Volcanology}

The abundances and distributions of volatile elements in a planetary body at birth influence the outcome of its evolution. Volatile elements can influence the existence and operation of plate tectonics, determine the composition and evolution of the atmosphere, and are important for the potential emergence of life. Among the rocky bodies in our Solar System, the Moon has long been considered the archetypal example of a volatile-free body. Such a dry Moon is consistent with the hypothesis that it formed from the debris of a giant collision between the early Earth and a Mars-sized body ${ }^{1}$. However, the detection of water at terrestrial-like abundances in lunar volcanic glasses has overturned the notion of a volatile-depleted Moon ${ }^{2}$. Writing in Nature Geoscience, Wetzel et al. ${ }^{3}$ analytically determine the carbon contents of the same lunar glasses and find that the small, but detectable, abundances of carbon and the degassing patterns they display are similar to those of Earth's mid-ocean ridge basalts further evidence that the Earth and Moon may share a common volatile source.

The discovery in 2008 of water in the glassy volcanic products of eruptions that occurred on the Moon over 3 billion years ago challenged the long-held assumption of a volatile-free Moon $^{2}$. Intriguingly, the lunar volcanic glasses contain hydrogen, fluorine, sulphur and chlorine at levels that all imply an origin from source magmas with similar volatile concentrations as parts of Earth's upper mantle ${ }^{2}$. Subsequent detection of water and other volatile elements in various types of lunar material supports a revised view of a Moon that contains at least some volatiles, although how much and how they are distributed is a matter of debate ${ }^{4}$.

The lunar volcanic glasses are thought to be the product of fire-fountain eruptions ${ }^{5}$, in which a jet of basaltic lava erupts through a vent, spattering droplets of lava that cool quickly to form glass. The explosiveness of a fire-fountain eruption, such as those observed in present-day Iceland (Fig. 1), is due to the degassing of volatile species dissolved in the magma. On Earth, these volatile species are typically water or carbon dioxide. On the Moon, however, it is unlikely that water or the other volatile elements detected thus far in the lunar volcanic glasses would have degassed under conditions in the lunar upper mantle ${ }^{5}$. Furthermore, variations in the volatile contents in the glasses suggest that minimal hydrogen was lost during the early stages of degassing ${ }^{2}$. 


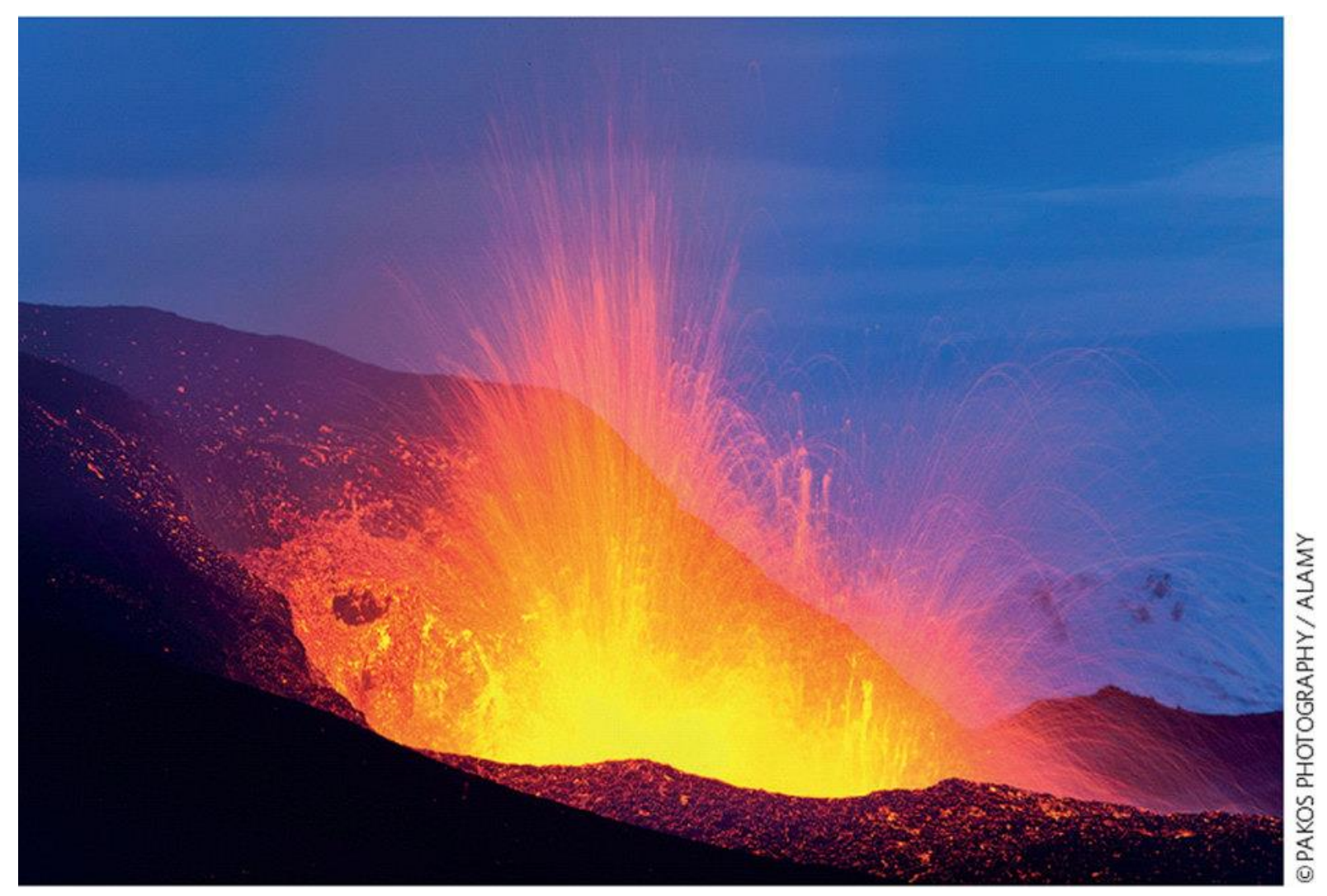

Figure 1: A fire-fountain eruption in Iceland. : Explosive volcanism on Earth is typically driven by the degassing of $\mathrm{H}_{2} \mathrm{O}$ or $\mathrm{CO}_{2}$. Wetzel et al. ${ }^{3}$ suggest that lunar basalts were sourced from a mantle similar to that of Earth, except one that is more reduced. Instead of $\mathrm{CO}_{2}$, they find that $\mathrm{CO}$ is the dominant carbon-bearing species degassing and driving the lunar fire fountains.

Carbon is thought to be a more likely culprit for the trigger of the fire-fountain eruptions ${ }^{6}$. Carbon-bearing species in silicate melts, especially those that are reduced, are not very soluble and thus degas easily from silicate melts. However, due to past limitations of available analytical techniques, the concentration of carbon in lunar magmas has been poorly constrained.

Wetzel et $a l .^{3}$ analysed the carbon concentrations of volcanic glasses and melt inclusions in samples from the Apollo 15 and Apollo 17 missions, taking advantage of analytical advances that have substantially reduced the limits on carbon detection. They find that the carbon and water contents both increase towards the centres of the glass beads, indicative of degassing processes. The melt inclusions, which were trapped within olivine crystals before eruption, should not have experienced volatile loss due to volcanic degassing. The carbon content of the melt inclusions - measured by Wetzel et al. to be about $50 \mathrm{ppm}$ - are expected to closely resemble that of their source mantle. This carbon content is similar to that measured from terrestrial basalts at mid-ocean ridges, in agreement with previously reported $\mathrm{H}, \mathrm{F}, \mathrm{S}$ and $\mathrm{Cl}$ contents.

Wetzel et al. then apply a terrestrial degassing model of carbon, oxygen and hydrogen species that they modify to calculate the solubility of these species at the pressures and temperatures of lunar magmas. They find that $\mathrm{CO}$ is initially the dominant gas species; with increasing 
degassing of $\mathrm{CO}$, eventually $\mathrm{H}_{2}$ and $\mathrm{H}_{2} \mathrm{O}$ also become important. This degassing scenario is consistent with the variations of $\mathrm{C}$ and $\mathrm{H}$ contents measured across the volcanic glass beads, suggesting that the fire-fountain eruptions were driven primarily by $\mathrm{CO}$ degassing.

Wetzel et al. suggest that the similarity in volatile contents may be the result of a common origin of the volatiles in the Earth and Moon, but this is not easy to explain by existing giant impact scenarios or what we know about the evolution of the Earth's interior. The authors compare the products of lavas erupted more than 3 billion years ago on the Moon to modern seafloor basalts, which have an upper mantle source undoubtedly influenced by billions of years of large-scale mantle geodynamics and plate tectonics. And, despite similar volatile contents, Earth's basalts contain ferric iron consistent with an oxidized mantle source ${ }^{7}$, whereas lunar samples collected by the various Apollo and Lunar missions are geochemically reduced and show a conspicuous absence of ferric iron ${ }^{8}$.

One possible explanation for this discrepancy is that the magma erupted on the surface does not necessarily reflect the redox conditions of its source mantle, due to decompression during the eruption process ${ }^{9}$. A decompression-driven redox change has been proposed ${ }^{6,10}$ for the same volcanic glasses analysed by Wetzel et al. In this model, graphite particles suspended in the melt are oxidized to form a CO-rich gas phase during decompression as the magma ascends ${ }^{10}$. Thus, the ascending magma is consequently more reduced than its source mantle material. Analyses of iron- and nickel-rich metallic blebs in the lunar volcanic glasses are consistent with this reduction mechanism ${ }^{10}$. However, none of the lunar glasses analysed so far contain graphite ${ }^{8}$.

Wetzel $e t a l .^{3}$ definitively show that carbon is present as a dissolved species in the erupted melt phase of lunar magmas, and suggest that there is sufficient dissolved carbon in lunar melts to drive fire-fountain eruptions ${ }^{5}$. Hence, graphite, if present, is not the sole source of carbon to drive degassing, nor is it necessarily required. Although Wetzel et al. do not definitively rule out graphite occurrence in lunar magmas, their findings suggest that the oxidation of graphite to $\mathrm{CO}$ may not explain the reduction of lunar basalts. Another mechanism is required to explain why the lunar volcanic glasses are reduced relative to midocean ridge basalts, despite similar volatile contents. 


\section{References}

Canup, R. M. \& Asphaug, E. Nature 412, 708-712 (2001).

Saal, A. E. et al. Nature 454, 192-195 (2008).

Wetzel, D. T., Hauri, E. H., Saal, A. E. \& Rutherford, M. J. Nature Geosci. 8, 755-758 (2015).

Robinson, K. L. \& Taylor, G. J. Nature Geosci. 7, 401-408 (2014).

Rutherford, M. J. \& Papale, P. Geology 37, 219-222 (2009).

Sato, M. in Proc. Lunar Planet. Sci. Conf. 10, 311-325 (1979).

Delano, J. W. Origins Life Evol. B 31, 311-341 (2001).

Delano, J. W. J. Geophys. Res. 91, 201-213 (1986).

Gaillard, F. \& Scaillet, B. Earth Planet. Sci. Lett. 403, 307-316 (2014).

Nicholis, M. G. \& Rutherford, M. J. Geochim. Cosmochim. Acta 73, 5905-5917 (2009). 